\title{
FORMATION OF THE MECHANISM OF SOCIO-ECONOMIC DEVELOPMENT OF UKRAINE
}

\author{
Olga Chirva ${ }^{1}$, Anna Chirva ${ }^{2}$, Natalia Malyarchuk ${ }^{3}$
}

\begin{abstract}
The subject of the research is the theoretical and methodological aspects of the formation of the mechanism of socio-economic development of Ukraine. Methodology. The study used the following general scientific methods: theoretical generalization; methods of positive and normative analysis, statistical analysis. The purpose of the work is to substantiate the formation of the mechanism of socio-economic development of Ukraine. Results. The purpose of the article is the formation of the mechanism of socio-economic development of Ukraine. Analysis of the socioeconomic status of households in Ukraine showed that the average monthly total income of one household in 2020 was $12248 \mathrm{UAH}$. Minor disproportions are observed because the urban household received on average 12620 UAH per month, while the rural household received $11470 \mathrm{UAH}$ per month. It was determined that on average per one person in a household (hereinafter people) the equivalent aggregate income (hereinafter income) was 5832 UAH per month, in urban households - $6096 \mathrm{UAH}$, in rural households - $5286 \mathrm{UAH}$. It was proved that the level of average monthly income per person was 2.8 times higher than the established subsistence minimum (2078 UAH). It was found that the main source of income in households with one child was income from work (77\%), and in households with three or more children the share of this income was 1.2 times lower. The socio-economic condition of Ukrainian households is analyzed. The structure of total resources of all households is examined The structure of total household expenditures is also analyzed. The distribution of users of Internet services by purpose is studied. The formation of the mechanism of socio-economic development of Ukraine in terms of sustainable development is carried out. It is proved that the mechanism of formation and development of socio-economic systems can be characterized as a mutually agreed system of legal and methodological support, based on the basic principles of territorial systems (sustainability, multilevel, partnership, dynamism, focus on local needs, public participation) and aimed at ensuring the welfare of the community, the well-being of residents and increasing the competitiveness of the territorial system, by developing appropriate tools.
\end{abstract}

Key words: mechanism, socio-economic development, households, income and expenditure of the population.

JEL Classification: E20, E69, J10

\section{Introduction}

Constant changes in the global market conditions, institutional and structural transformations of the national economy require the development of a sustainable socio-economic development mechanism based on appropriate tools, goals and principles of improvement, efficiency and development of economic entities and relevant territories that implement innovations and develop new products and services. Ensuring sustainable socio-economic development of Ukraine is impossible without improving the relevant

Corresponding author:

${ }^{1}$ Pavlo Tychyna Uman State Pedagogical University, Ukraine.

E-mail: chyrva81@ukr.net

ORCID: https://orcid.org/0000-0001-5246-9001

${ }^{2}$ Pavlo Tychyna Uman State Pedagogical University, Ukraine.

E-mail: ch56@i.ua

ORCID: https://orcid.org/0000-0003-3791-6111

${ }^{3}$ Pavlo Tychyna Uman State Pedagogical University, Ukraine.

E-mail: natashamalyarchuk2612@gmail.com

ORCID: https://orcid.org/0000-0002-5284-1376 mechanisms of activity and management practices of the development of the relevant system.

To ensure sustainable socio-economic development of the population in modern conditions of activity the necessary basis is the effective formation and use of resource potential and its intensification of innovation processes. The effectiveness of sustainable socio-economic growth of the population and economic entities is determined by the ability of the management system to influence all business processes and coordinate its internal capabilities with economic 
and incentive tasks to ensure competitiveness based on the development of the mechanism and its implementation in the global dimension.

In modern conditions of transformation of economic relations and socio-economic systems, reforming the institutional and legal field of socio-economic development of our country, which is characterized by the gradual introduction of European norms, decentralization processes on the background of complex geopolitical and economic challenges, there is a need for an effective system to monitor socioeconomic development, which would allow to make certain management decisions promptly and to determine their impact on the relevant processes. Today, many strategic programs and plans for regional development do not contain a clear rationale for the system of financing. The implementation of strategic programs and plans affects the level of socio-economic development. All this requires constant monitoring of statistical indicators and the results of sociological surveys to assess the socio-economic development of the regions. That is why the study of the current state of socio-economic security of the population, the formation of the mechanism of socio-economic development of territories is quite relevant and requires thorough research.

\section{Analysis of the socio-economic status of Ukrainian households}

In recent years there has been a particular aggravation of socio-economic problems of rural development. This is due, on the one hand, to the global process of urbanization, inherent in our country, and on the other hand - economic, social, cultural, spiritual decline of the Ukrainian village, due to a number of problems associated with the inefficient use of socio-economic potential. As a result, rural areas of Ukraine today face a number of challenges caused by the destruction of social and communal infrastructure, deteriorating quality of human capital, growing socio-demographic inequality, inefficient use of available natural resources, and deteriorating environmental conditions. On the contrary, effective reforming and ensuring socioeconomic development of indigenous rural areas is an important reserve for equalizing spatial and structural socio-economic distortions, the basis for developing real sectors of the economy, stimulating business activity, improving infrastructure and quality of life (Vasyltsiv, 2013).

The average aggregate monthly income per household in 2020 was 12,248 UAH. An urban household received an average of 12,620 UAH per month, while a rural one received 11,470 $\mathrm{UAH}$. On average per person in a household (hereinafter referred to as a person), the equivalent aggregate income (hereinafter referred to as income) was 5,832 $\mathrm{UAH}$ per month, in urban households - 6,096 UAH, in rural households $5,286 \mathrm{UAH}$. The level of average monthly income per person was 2.8 times higher than the established living wage (2 $078 \mathrm{UAH})$. Average per capita household income in 2020 compared with the previous year grew faster than the consumer price index for this period: $103.8 \%$ vs. $102.7 \%$, respectively.

Inequality in the distribution of aggregate income is characterized by the Lorenz curve and the concentration coefficient (Gini index), which takes values from 0 (equal distribution of income among the population) to 1 (all income belongs to one person). The Gini index of aggregate income decreased from 0.249 in 2019 to 0.247 in 2020 .

The ratio of the minimum level of aggregate income among the poorest $10 \%$ of the population to the maximum level among the poorest $10 \%$ of the population decreased in Ukraine from 3 to 2.9 times, among urban residents - from 3.1 to 2.9 times, and among rural residents - from 2.8 to 2.7 times. The wealthiest $20 \%$ of the population received $36 \%$ of total aggregate income in 2020, as in the previous period. The ratio of aggregate incomes of the most and the least wealthy $10 \%$ of the population remained at the level of 2019 and amounted to 4.9.

The share of aggregate income of the $40 \%$ of the least well-off was, as in 2019, a quarter of all aggregate income. The ratio of the growth rate of the average per capita equivalent aggregate incomes of $40 \%$ of the least well-off and the total population was 1.02 times in 2020 (in $2019-0.97$ times). The proportion of the population with per capita equivalent of total monthly income below $50 \%$ of the median level of total income (2 $555 \mathrm{UAH}$ ) in 2020 is $4 \%$ (in 2019 $4.2 \%$ and $2478 \mathrm{UAH}$ respectively).

Compared to 2019, the differentiation of the level of well-being of the population, calculated by the criterion of monetary income, decreased. The Gini index was 0.260 in 2020 compared to 0.265 in 2019 . The minimum level of monetary income among the richest $10 \%$ of the population exceeded the maximum level among the poorest $10 \%$ of the population by 3.1 times (3.3 times in 2019). The richest $10 \%$ of the population received 5.3 times more income than the poorest $10 \%$ of the population (5.5 times).

M. Kuybida, K. Chernitsyna believe that "The most important task of the development of Ukrainian society is to improve the quality of management of socioeconomic development of the state and regions. The need to improve state regulation of socio-economic development of regions is due to the inefficient use of financial and material resources aimed at development, the inability of most regions to solve their socioeconomic problems, the limited powers of regional authorities to regulate the rational use of resources and create conditions for improving the quality of life" (Kuybida \& Chernitsyna, 2010). 
Households met their needs at the expense of resources from various sources. Average monthly total resources (hereinafter - resources) per household amounted to $12,432 \mathrm{UAH}$, urban - 12,806 UAH, rural - 11,651 UAH and increased compared to 2019 in Ukraine as a whole to $3 \%$, in urban areas - to $1.7 \%$, in rural areas - to $5 \%$. Resources per person, on average $5920 \mathrm{UAH}, 6186 \mathrm{UAH}$ and $5369 \mathrm{UAH}$, respectively.

In the structure of resources of households, the predominant part (94\%) consisted of cash incomes (in 2019 - 92\%). In urban households, their share increased by 1.9 percentage points. and amounted to $96 \%$, and in rural areas - by 2 percentage points and amounted to $88 \%$.

Compared to 2019, the share of income from employment increased by 0.3 percentage points to $64 \%$ of household resources. At the same time, the share of wages and salaries (58\%) increased by 1 percentage point, and the share of income from entrepreneurship and self-employment (6\%) decreased by 0.7 percentage points. The share of pensions, scholarships, and social benefits (including cash and noncash benefits and subsidies) increased by 0.9 percentage points to one-fifth of household resources, including benefits and subsidies for housing, utilities (cash and noncash) as $1 \%$ (1.4\% in 2019) of all household resources.

Significant differences were the structures of formation of aggregate resources of urban and rural households.

Employment income for urban households accounted for $70 \%$ of resources (their share increased by 0.3 percentage points compared to 2019), a fifth was pensions, scholarships, and social benefits provided in cash (up 1.8\%).
Half of the resources of rural households were income from employment, 0.3 percentage points more than in 2019. Traditionally important for this group of households was such a source of resources as income from personal subsidiary farming, which accounted for $16 \%$ of their total income (17\% in 2019). Pensions, scholarships, and social benefits provided in cash continued to be a significant source of resources, with their share increasing by 1.6 percentage points to one-fifth.

Bil M. M., Mulska O. P. note that the problematics of consumer research has a multifaceted nature. On the one hand, modern society is evolving as a consumer society. The ideas of saving, conserving environmental resources with the encouragement of long-term consumption are increasingly being promoted. On the other hand, the priorities of consumerism persist with the growing rights of consumers, in particular with regard to access to quality products and in sufficient quantity. For developing or transforming societies, to which Ukraine belongs, the study of consumption and cost structure is rather of an acute social nature, which, however, is intertwined with the structural weaknesses of the economy and the contradictions of innovative development. Households are an important object of analysis of consumption patterns, highlighting its main patterns. These institutional units make it possible to "individualize" the assessment of the needs of the population and to identify risk trends in the relationship between economic growth and well-being (Bil \& Mulska, 2021).

The main source of aggregate resources in households with one child was income from work (77\%), while in households with three or more children the share was 1.2 times lower. Households with many children had $9 \%$ of income from private farming and self-sufficiency,

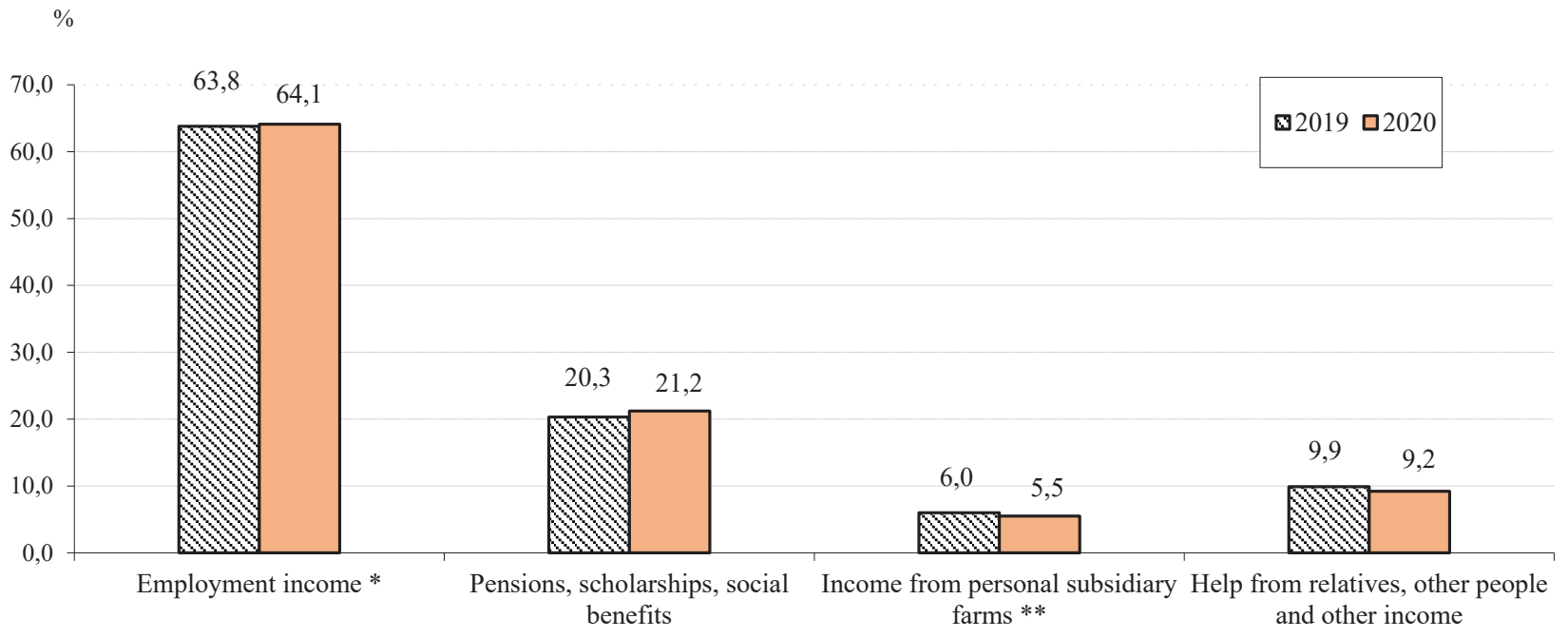

Figure 1. The structure of the total resources of households

* Wages, income from entrepreneurship and self-employment.

** Income from the sale of agricultural products and the value of consumed products obtained from personal subsidiary farms. 
while pensions, scholarships, and social payments (cash and non-cash) accounted for one-fifth of all resources. In households without children, labor income accounted for $53 \%$ of resources (down 3 percentage points from 2019), pensions, scholarships, and social benefits (cash and noncash) for 31\% (up 4 percentage points), and income from private farming and self-growing for $6 \%$ (down 0.4 percentage points).

Average monthly total expenditures (hereinafter referred to as costs) per household were 9,524 UAH, urban - 9,820 UAH, rural - 8,903 UAH. Average expenses per person amounted to $4535 \mathrm{UAH}$ per month, in urban households - $4744 \mathrm{UAH}$, in rural households - 4103 UAH.

Household consumer spending accounted for 91\% of all total spending, down 0.1 percentage point from 2019 (Figure 2).

Households spent $49 \%$ of all spending on food (including meals outside the home) (0.7 percentage point more than in 2019). Households spent 39\% of all total spending on nonfood items and services (excluding out-of-home food), 0.9 percentage points less than in the previous period. Spending on alcoholic beverages and tobacco products accounted for $1.2 \%$ and $2.3 \%$ of household spending, respectively ( $1.2 \%$ and $2 \%$ in 2019). The share of non-consumer expenditures, as in the previous period, was $9 \%$ of total household expenditures.

Households spent $39 \%$ of their total spending each month on non-food items and services (not including the cost of food outside the home) (40\% in 2019). The average household spent $14 \%$ of total expenses on housing (including current repairs), water, electricity, gas, and other fuels; $5 \%$ on closet renovations; and $1 \%$ to $4 \%$ of total expenses on other areas of consumption, education, recreation and culture, the purchase of household goods, household appliances and current housing maintenance, communications, transportation, health care, etc.).

Consumer spending on non-food goods and services of urban households was 1.3 times higher than that of rural households, in particular, on recreation and culture, education, housing, water, electricity, gas and other fuels, communications - 3-1.2 times, on transport, health care (drugs and medical services), household items, household appliances, current housing, clothing and shoes $-13-5 \%$ respectively.

Karp'yak M. O., Stegney M. I. believe that "The modern dynamism of socio-economic development poses new challenges to the state associated with the need to confront the negative consequences of continuous transformations, the most striking of which we consider the growth of inequality and social polarization caused by changes in the social structure of society. A consequence of these changes today is the spread of such a negative social phenomenon as social exclusion, which in the 1960s was interpreted by the American sociologist T. Parsons as a concomitant and almost inevitable effect of modern society.

The problem of social exclusion in Ukraine and its regions is primarily associated with dysfunctional processes of regulation of the main spheres of life, including employment, wages and access to social services. In addition, the presence of other destabilizing factors of an economic nature creates a significant risk of people being socially excluded today, including: the presence of significant imbalances in the labor market, including high levels of unemployment and job losses; a significant level of poverty, especially among the working population; the risk of not getting a job in accordance with the level of qualifications one has acquired and other factors that pose a particular threat

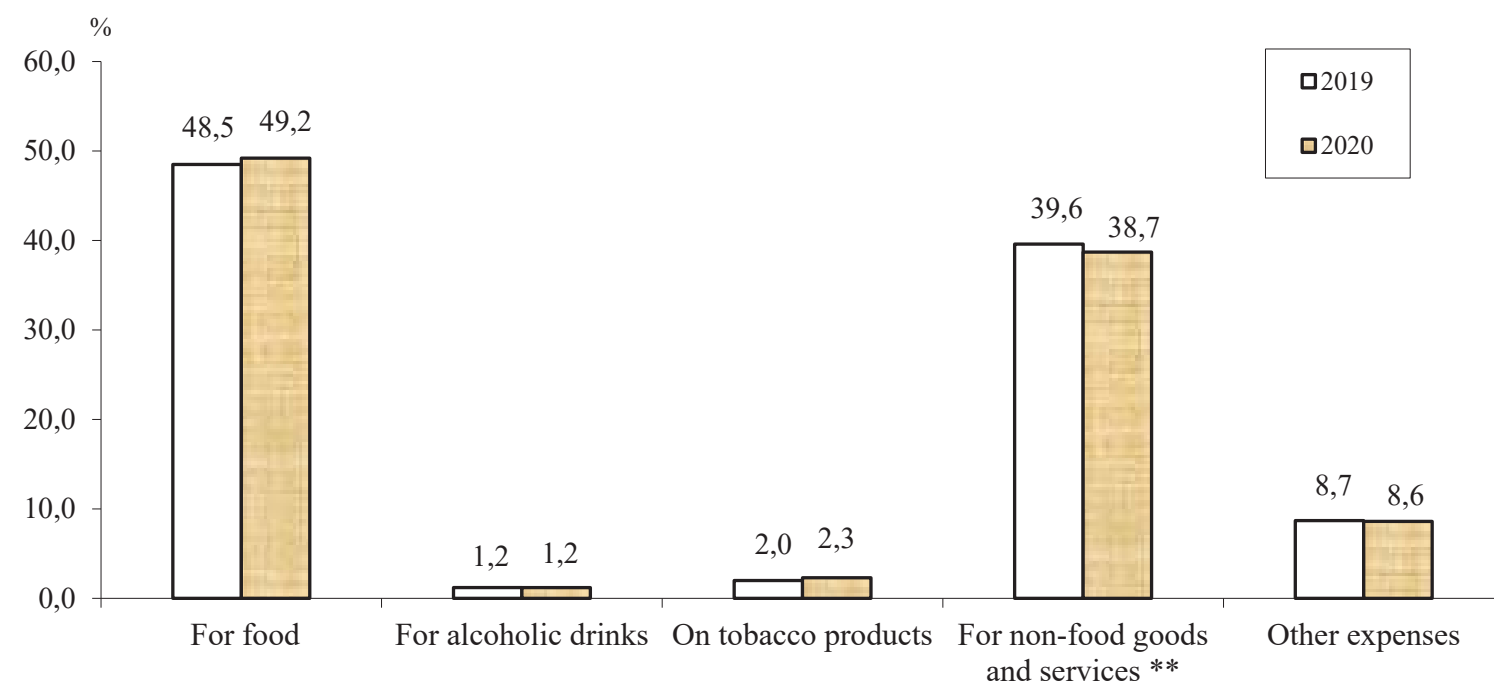

Figure 2. Structure of total household expenditures

${ }^{*}$ Including the cost of meals outside

** Without the cost of meals outside 
to the preservation and development of the state's human potential" (Karp'yak \& Stegnei, 2021).

"Innovation, as part of an enterprise's competitive advantage, is not only a strategically important resource, but also an area of potential loss when financial support is unsustainable. The close relationship between competitiveness, investment attractiveness and innovation is a crucial area of economic analysis"(Irtyshcheva at el., 2021).

Modern information and communication technologies, in particular the Internet, are becoming more accessible and increasingly common among the population (Appendix 9). According to the survey, the proportion of people who reported using the Internet was $76 \%$ (70\% in 2019), among residents of large cities such people were $83 \%(80 \%)$, in small towns-78\%(74\%).Inruralareas, theproportion ofpeople who reported using the Internet increased from $56 \%$ to $64 \%$ compared to 2019 . In households with children, $85 \%$ of people used the Internet $(79 \%$ in 2019) and 65\% without children (60\%). The percentage of households with access to internet services at home increased from $66 \%$ to $79 \%$. The percentage of children under the age of 18 who used the Internet was $76 \%$ (73\% in 2019).

Among Internet users, $85 \%$ reported using the World Wide Web at least once a day; at least once a week but not every day, $13 \%$; and less than once a week, $2 \%$.

Of all users, $86 \%$ said they use the Internet at home, $79 \%$ say they use it somewhere through their cell phone or smart phone, $18 \%$ say they use it at work, $10 \%$ say they use it at their place of study, $8 \%$ say they use it elsewhere (at friends, acquaintances), $0.7 \%$ say they use it somewhere through another mobile access device, $0.4 \%$ say they use it in a public Internet access center and $0.1 \%$ say they use it in a commercial Internet access center.

The population used the Internet for a variety of purposes. The most common Internet services for users were downloading movies, pictures, music, watching TV or videos; listening to radio or music; playing or downloading videos or computer games - $72 \%$, $59 \%$ said the purpose of using the Internet was to communicate, $36 \%$ said the purpose was banking, $34 \%$ was to make phone calls over the Internet, $33 \%$ sent (received) email, $28 \%$ was to find health information for themselves and others, $21 \%$ was to order (buy) goods and services, $20 \%$ was to read or download periodicals online. Compared to 2019, the share of users who used the Internet for banking purposes increased by 1.7 times.

"The management of the financial autonomy of a region must: ensure the achievement of the goals of economic development of the region of the whole system; be based on the principles of democratization of management, which will allow to direct the economic activity of the entire population of the territory to use the available reserves; organically fit into the economic, political and organizational structure of the state; be flexible, able to rebuild or to complete with the specifics of development of each city and district, located in the region" (Melnychuk, Chyrva, Chvertko, Chyrva \& Berbets, 2020).

Children under 18 primarily used the Internet to download movies, pictures, and music; watch TV or videos; listen to radio or music; play or download videos or computer games ( $89 \%$ of users this age), $72 \%$ used the Internet for educational, professional, or private purposes through online courses (except complete online courses), half used the Internet to participate in social media, communicate, $21 \%$ to send (receive) e-mail and telephone calls over the Internet, and $10 \%$ used the Internet to read or download periodicals.

$83 \%$ of men and $80 \%$ of women used the World Wide Web. Males were more likely than females to use the Internet to download movies, pictures, music, watch TV or videos; listen to radio or music; play or download videos or computer games, read or download online periodicals, and download software. Women mostly used the Internet to participate in social networks, communicate, bank, search for healthrelated information, both for themselves and for others, and to order (buy) goods and services.

To ensure sustainable socio-economic development of the population, in our view, it is necessary to form an appropriate mechanism for implementation.

\section{The mechanism of socio-economic development of Ukraine in terms of sustainable development}

Kholodniuk Z. V. notes that "During the financial and economic crisis there is a change in the economic mechanism, which in one way or another affects the economy and the social situation in each region. Inter-regional differences are growing, which leads to changes in regional policy: structural changes, the rejection of centralism and the transition to federalism in public administration, the reduction of the distributive function of the state budget, and so on. These processes are inevitably aimed at expanding the economic independence of regions, the development of local self-government, which in conditions of unstable economic development is a tool to overcome the crisis" (Kholodniuk, 2011).

Kovalchuk V. G. believes that "The state mechanism of management in Ukraine should be considered as a complex, which includes several independent mechanisms, each of which is able to influence in one way or another on the objects of management. This is a system, which, in addition to the tools of influence on the object of management, also includes methods, levers, policies, appropriate regulatory and information 


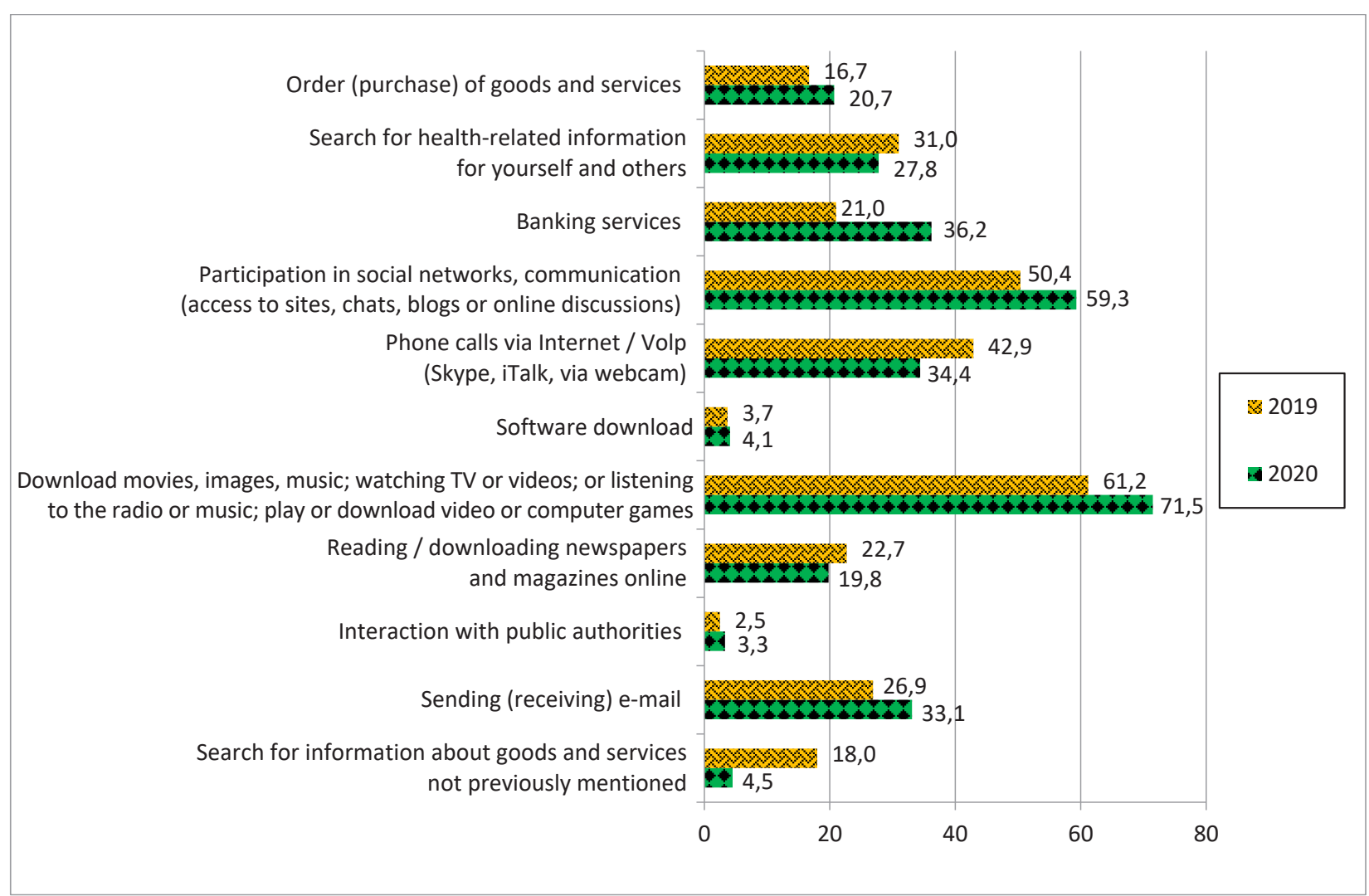

Figure 3. Distribution of users of Internet services by purpose of use (\% of population who reported that used the Internet)

support, and so on. There is a rich evolutionary experience of changing and improving the mechanism of management of remote territorial components of the state or regions. More thoroughly this problem began to be solved with the introduction of administrative-territorial formations. Administrative structures of regional management emerged and are constantly being improved out of practical expediency. The ongoing processes of economic and social transformation determine the objective need for theoretical rethinking of the internal content and purpose of all elements of the mechanism of regulation of socio-economic development of the region" (Kovalchuk, 2013).

Stehnei M., Irtysheva I., Gurina O. to note "First of all, indirect methods include stimulating the development of the regional economy and job creation, stimulating the social consciousness of business leaders, expanding public-private partnerships, comprehensive support for innovation and science development in the region, implementing relevant social innovations, and debunking the regional economy" (Stehnei, Irtysheva \& Gurina, 2018).

The mechanism of formation and development of socio-economic systems can be described as a mutually coordinated system of legal and methodological support, based on the fundamental principles of territorial systems (sustainability, multilevel, partnership, dynamism, focus on local needs, population participation) and aimed at ensuring community well-being, the well-being of residents and the benefit of future generations and increasing the competitiveness of the territorial system (Figure 4).

Among the list of methodological support for the mechanism of formation and development of decentralized socio-economic territorial systems an important place belongs to the program-target method, focused on the efficiency of resources based on the system approach and the method of development of local communities using local resources based on the situational approach.

The proposed mechanism for the formation and development of decentralized socio-economic territorial systems requires the improvement of sociohumanitarian guidelines and state-building capacity of the national identity in the direction of strengthening social protection guarantees and public-private partnerships in accordance with the Sustainable Development Goals by 2030. The main direction of modernization of the strategic directions of territorial and national socio-economic development should be a human-centered approach that prioritizes the interests of socio-economic development.

"It is proved that the state policy in the field of human capital development in Ukraine today does not meet the modern challenges associated with the rapid 


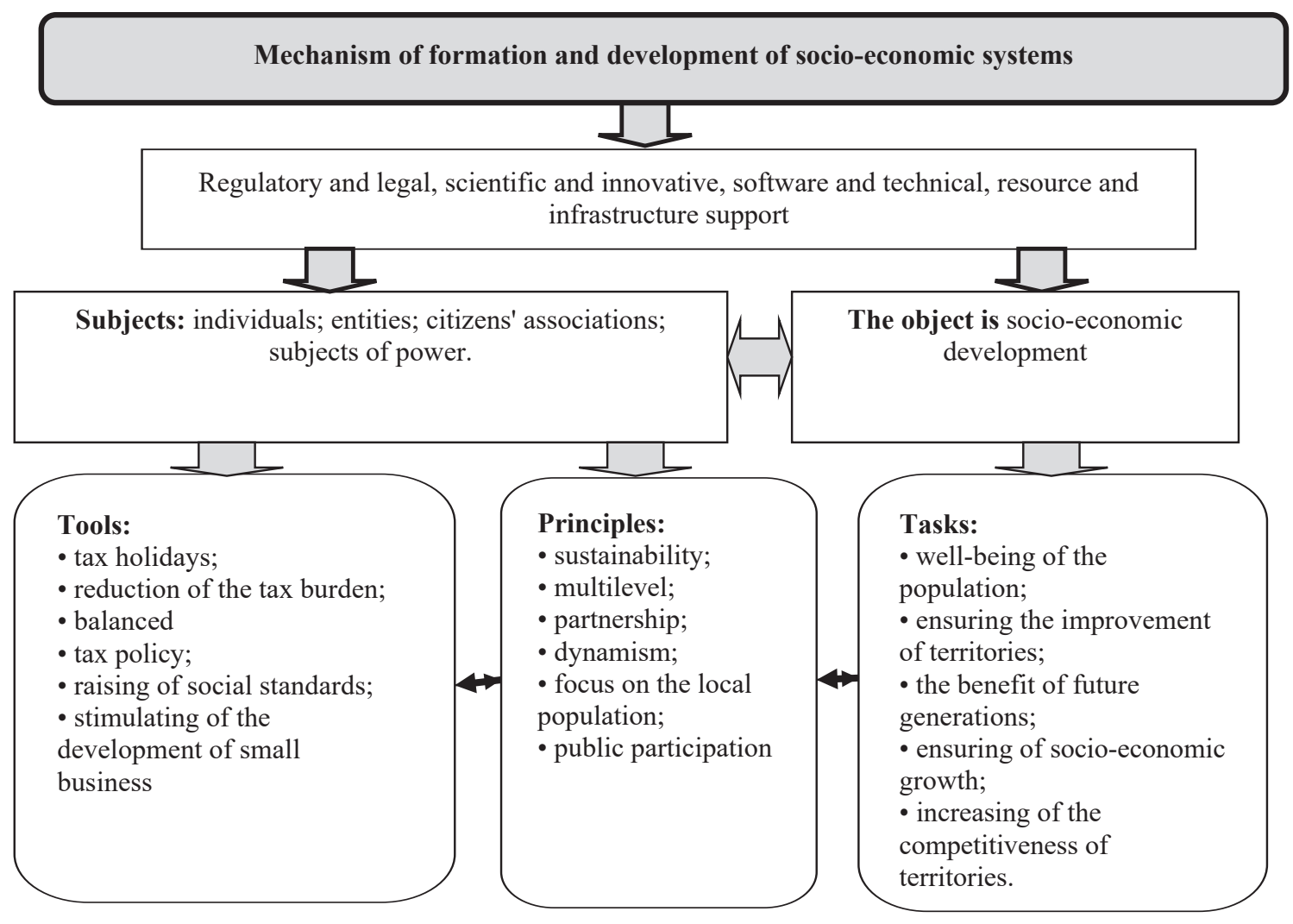

Figure 4. The mechanism of formation and development of socio-economic systems

development and proliferation of digital technology. The consequences of this already today are growing inequality in the labor market, the lack of highly qualified specialists with digital competencies at the proper level, increasing trends of emigration of intellectual capital and the gene pool of the nation abroad, the shrinkage of the "middle class" and the strengthening of social degradation. The solution of these problems requires the development and implementation of a unified state strategy for human capital development, which will stimulate its formation, development and effective use in the vector of transition to a new technological mode, will ensure economic growth and high living standards of the population"(Irtyshcheva, Trushliakova \& Sirenko, 2020).

\section{Conclusions}

Analysis of the socio-economic status of households in Ukraine showed that the average monthly aggregate income per household in 2020 was $12248 \mathrm{UAH}$. There are slight disparities, as an urban household received on average $12620 \mathrm{UAH}$ per month, and a rural one - $11470 \mathrm{UAH}$ per month. It was determined that on average per person in a household (hereinafter people) the equivalent aggregate income (hereinafter income) was 5832 UAH per month, in urban households - $6096 \mathrm{UAH}$, in rural households $5286 \mathrm{UAH}$. It was proved that the level of average monthly income per person was 2.8 times higher than the established subsistence minimum (2078 hryvnia). It was found that the main source of income in households with one child was income from work (77\%), and in households with three or more children the share of this income was 1.2 times lower.

The formation of the mechanism of socio-economic development of Ukraine in terms of sustainable development is carried out. It is proved that the mechanism of formation and development of socioeconomic systems can be characterized as a mutually agreed system of legal and methodological support, based on the basic principles of territorial systems (sustainability, multilevel, partnership, dynamism, focus on local needs, public participation) and aimed at ensuring the welfare of the community, the well-being of residents and increasing the competitiveness of the territorial system, by developing appropriate tools.

\section{References:}

Vasyltsiv, T. G., Boyko, V. V., \& Popovichenko, Yu. A. (2013). Strategic priorities of the state policy of social and economic development of rural areas. Socio-economic problems of the modern period of Ukraine, 6, 79-87. 
State Statistics Service of Ukraine (2021). Available at: http://www.ukrstat.gov.ua/

Kuybida, M., \& Chernitsyna, K. (2010). State regulation of socio-economic development of regions. Scientific Bulletin "Democratic Governance". Available at: http://lvivacademy.com/vidavnitstvo_1/visnik5/fail/+Kujbida.pdf

Bill, M. M., \& Mulska, O. P. (2021). Models of consumer behavior of households and regional features of their formation in Ukraine. Regional economy, 2(100), 53-60. DOI: https://doi.org/10.36818/1562-0905-2021-2-5

Karp'yak, M. O., \& Stegney, M. I. (2021). Assessment of social exclusion in Ukraine and its impact on the socio-economic development of the state at the national and regional levels. Regional economy, 2(100), 72-82. DOI: https://doi.org/10.36818/1562-0905-2021-2-7

Irtyshcheva, I., Sukhostavets, A., Falovych, V., Kovbasa, O., Liashok, O., \& Kolesnik, E. (2021). Modelling the Innovative Competitiveness of an Enterprise with a Change in Investment Provision. Estudios de Economía Aplicada, 39(5): Special Issue: Innovation in the Economy and Society of the Digital Age. DOI: https://doi.org/10.25115/eea.v39i5.5041

Kholodniuk, Z. V. (2011). Improving the mechanisms of implementation of socio-economic policy of the state in the management of the region. Public administration: improvement and development, 7. Available at: http://www.dy.nayka.com.ua/?op=1\&z=580

Melnychuk, Yu. M., Chyrva, O. H., Chvertko, L. A., Chyrva, H. M., \& Berbets, V. V. (2019). The Role of Management in the Financial Independence of the Region. TEM Journal, 8(2), 584-590. Available at: http://www.temjournal.com/content/82/TEMJournalMay2019_584_590.pdf

Stehnei, M., Irtyshcheva, I., \& Gurina, O. (2018). Financial mechanism of the socio-oriented economic development of the Black Sea region. Baltic Journal of Economic Studies, 4, 202-208. DOI: https://doi.org/ $10.30525 / 2256-0742 / 2018-4-4-202-208$

Kovalchuk, V. G. (2013). Improving of the mechanism of public management by sustainable development of the region. Available at: http://www.dridu.dp.ua/zbirnik/2013-01(9)/13kvgsrr.pdf

Irtyshcheva, I., Trushliakova, A., \& Sirenko, I. (2020). Strategic human capital management in the context of digitalization. Baltic Journal of Economic Studies, 6(5), 178-183. DOI: https://doi.org/10.30525/2256-0742/20206-5-178-183 